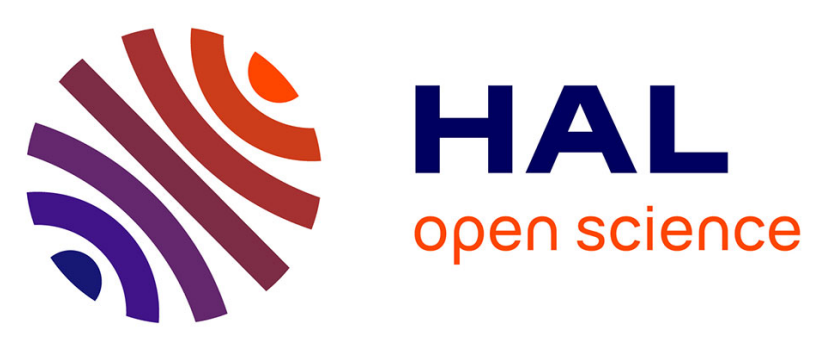

\title{
Chromium valence change in trivalent chromium conversion coatings on aluminium deposited under applied potentials
}

Jiantao Qi, Jolanta Swiatowska, Peter Skeldon, Philippe Marcus

\section{To cite this version:}

Jiantao Qi, Jolanta Swiatowska, Peter Skeldon, Philippe Marcus. Chromium valence change in trivalent chromium conversion coatings on aluminium deposited under applied potentials. Corrosion Science, 2020, 167, pp.108482. 10.1016/j.corsci.2020.108482 . hal-03049594

\author{
HAL Id: hal-03049594 \\ https://hal.science/hal-03049594
}

Submitted on 11 Dec 2020

HAL is a multi-disciplinary open access archive for the deposit and dissemination of scientific research documents, whether they are published or not. The documents may come from teaching and research institutions in France or abroad, or from public or private research centers.
L'archive ouverte pluridisciplinaire $\mathbf{H A L}$, est destinée au dépôt et à la diffusion de documents scientifiques de niveau recherche, publiés ou non, émanant des établissements d'enseignement et de recherche français ou étrangers, des laboratoires publics ou privés. 
archives-ouvertes

\section{Chromium valence change in trivalent chromium conversion coatings on aluminium deposited under applied potentials}

Jiantao Qi, Jolanta Swiatowska, Peter Skeldon, Philippe Marcus

\section{To cite this version:}

Jiantao Qi, Jolanta Swiatowska, Peter Skeldon, Philippe Marcus. Chromium valence change in trivalent chromium conversion coatings on aluminium deposited under applied potentials. Corrosion Science, Elsevier, 2020, 167, pp.108482. 10.1016/j.corsci.2020.108482 . hal-03049594

\section{HAL Id: hal-03049594 \\ https://hal.archives-ouvertes.fr/hal-03049594}

Submitted on 11 Dec 2020

HAL is a multi-disciplinary open access archive for the deposit and dissemination of scientific research documents, whether they are published or not. The documents may come from teaching and research institutions in France or abroad, or from public or private research centers.
L'archive ouverte pluridisciplinaire HAL, est destinée au dépôt et à la diffusion de documents scientifiques de niveau recherche, publiés ou non, émanant des établissements d'enseignement et de recherche français ou étrangers, des laboratoires publics ou privés. 
Short Communication

\title{
Chromium valence change in trivalent chromium conversion coatings on aluminium deposited under applied potentials
}

\author{
Jiantao Qi ${ }^{\mathrm{a}, \mathrm{c}, *}$, Jolanta Światowska ${ }^{\mathrm{b}}$, Peter Skeldon ${ }^{\mathrm{c}}$, Philippe Marcus $^{\mathrm{b}}$ \\ ${ }^{a}$ College of New Energy, China University of Petroleum (East China), Qingdao, 266580, PR China \\ ${ }^{\mathrm{b}}$ PSL Research University, Chimie ParisTech - CNRS, Institut de Recherche de Chimie Paris, 11 Rue Pierre et Marie Curie, 75005, Paris, France \\ ${ }^{\mathrm{c}}$ Corrosion and Protection Center, The University of Manchester, Manchester, M13 9PL, United Kingdom
}

\section{A R T I C L E I N F O}

\section{Keywords:}

Trivalent chromium

Hexavalent chromium

Conversion coating

Hydrogen peroxide

Oxygen reduction

\begin{abstract}
A B S T R A C T
The electroassisted (EA) deposition of trivalent chromium conversion coatings on aluminium is investigated with a focus on the influence of applied potential on the chromium valence state, as determined by Raman spectroscopy. The morphology and compositions of the coatings were investigated by scanning electron microscopy and energy-dispersive spectroscopy. The EA coatings were formed in naturally-oxygenated SurTec 650 chromitAl solution at constant potentials of -1.5 and $-0.5 \mathrm{~V}_{\mathrm{SCE}}$. The coatings contained chromium and zirconium constituents. The potentials resulted in net cathodic and anodic current densities, respectively, during the coating growth. Comparisons were made with coating formation at the open-circuit potential (OCP). The coating thickness increased in order $-0.5 \mathrm{~V}_{\mathrm{SCE}}<\mathrm{OCP}<-1.5 \mathrm{~V}_{\mathrm{SCE}}$, a result of increasing alkalinity from the cathodic reaction that facilitates deposition of the coating constituents. Fresh coatings formed at $-1.5 \mathrm{~V}_{\mathrm{SCE}}$ revealed the presence of $\mathrm{Cr}^{6+}$ species. By contrast, $\mathrm{Cr}^{6+}$ species were not resolved in the coating formed at $-0.5 \mathrm{~V}_{\mathrm{SCE}}$. It is proposed that less $\mathrm{H}_{2} \mathrm{O}_{2}$ is generated at $-0.5 \mathrm{~V}_{\mathrm{SCE}}$ to oxidize $\mathrm{Cr}^{3+}$ coating species.
\end{abstract}

\section{Introduction}

Trivalent chromium conversion (TCC) coating treatments are regarded as eco-friendly replacements of toxic chromate conversion coating processes [1-4]. A typical trivalent bath may contain hexafluorozirconate, trivalent chromium sulphate and supplemental ingredients such as fluoride species [5,6]. The fluoride component can activate the surface by thinning the surface oxide film to promote the coating formation [7]. The resultant coatings on aluminium and aluminium alloys display a two-layer coating structure, consisting of an outer $\mathrm{Zr}$-/Cr-rich layer over an alumina-rich layer containing fluorine species [8-11]. However, hexavalent chromium (chromate) species have been identified by Raman spectroscopy in freshly-formed coatings on aluminium $[9,12]$. It has been shown that the trivalent chromium can be oxidized by hydrogen peroxide generated by oxygen reduction with a 2e pathway $[9,13]$.

Li et al. [14] evidenced chromate species preferentially formed near copper-rich particles in a TCC coated AA2024 alloy, while remaining undetectable on the particle-free matrix. This correlated with the catalytic role of the cathodic particles in $\mathrm{H}_{2} \mathrm{O}_{2}$ formation and with the locally enhanced cathodic reactions during conversion treatment. Furthermore, more chromate was recorded on terraces near copper-rich particles during immersion in sodium sulphate solution with a small $\mathrm{H}_{2} \mathrm{O}_{2}$ addition $(0.01 \mathrm{v} / \mathrm{v})$ compared with the absence of $\mathrm{H}_{2} \mathrm{O}_{2}$, confirming the effectiveness of $\mathrm{H}_{2} \mathrm{O}_{2}$ as an oxidant of $\mathrm{Cr}^{3+}$ species. Other work correlated $\mathrm{H}_{2} \mathrm{O}_{2}$ generation with colorimetric measurements using the titanly reagent and revealed that fluoride in the reaction solution significantly increased $\mathrm{H}_{2} \mathrm{O}_{2}$ formation [13].

Notably, $\mathrm{Cr}^{6+}$ species were detected on TCC coated AA2024 alloy after the coating was aged in air for more than $1 \mathrm{~h}$ but were undetectable in freshly-formed coatings, which was attributed to insufficient dissolved oxygen in the bath $[7,14]$. However, a chromate component was found in freshly-formed coatings on aluminium [9]. Of possible significance to this discrepancy, the steady open-circuit potential (OCPs) during conversion treatments of AA2024 alloy is positively shifted (to $-0.8 \mathrm{~V}_{\mathrm{SCE}}$ ) compared with aluminium $\left(-1.5 \mathrm{~V}_{\mathrm{SCE}}\right.$ ) $[9,15]$, suggesting that reduction of oxygen to form hydrogen peroxide rather than hydroxyl ions may depend on the potential. With respect to electroassisted (EA) deposition of TCC coating formation, Dong et al. reported coatings containing zirconium and trivalent chromium oxides, similar to coatings formed under the open-circuit potential $[8,16]$.

The influence of the electrochemical potential of the substrate on the formation of $\mathrm{H}_{2} \mathrm{O}_{2}$ and $\mathrm{Cr}^{6+}$ species during coating growth on aluminium is the focus of the present research. This factor has received

\footnotetext{
* Corresponding author at: College of New Energy, China University of Petroleum (East China), Qingdao, 266580, PR China.

E-mail address: jiantao.qi@upc.edu.cn (J. Qi).
} 
little previous attention. The study specifically investigated the role of constant applied potentials of $-0.5 \mathrm{~V}_{\mathrm{SCE}}$ and $-1.5 \mathrm{~V}_{\mathrm{SCE}}$ during conversion treatments in a commercial TCC solution. These potentials result in net anodic and cathodic polarization of the aluminium, respectively. Scanning electron microscopy (SEM) with energy-dispersive Xray spectroscopy (EDS) was used to characterize the coatings. Additionally, the coated specimens were analysed by Raman spectroscopy to determine the chromium chemistry and its dependence on the applied potential and immersion time.

\section{Experimental procedure}

\subsection{Materials and regnant}

Specimens, of dimensions $30 \times 12 \times 0.3 \mathrm{~mm}$, were cut from 99.97 $\%$ aluminium sheet, rinsed sequentially in acetone, ethanol and deionized water, then electropolished in a mixture of perchloric acid and ethanol (1:4 volumes) at $20 \mathrm{~V}$ for $240 \mathrm{~s}$ below $10^{\circ} \mathrm{C}$. They were then rinsed in ethanol and deionized water and dried in a stream of cool air.

SurTec 650 chromitAL (SurTec Corp.) was diluted with deionized water at a volume ratio of 1:4 and then $1 \mathrm{wt} . \% \mathrm{NaOH}$ droplets were used to adjust the solution $\mathrm{pH}$ to 3.9 . Inductively coupled plasmaatomic emission spectroscopy (ICP-AES) analysis of the bath, using a Perkin-Elmer Optima 5300 dual view instrument, revealed a $\mathrm{Zr} / \mathrm{Cr}$ atomic ratio of $0.70 \pm 0.02$. The composition of SurTec 650 chromitAL is subject to commercial confidentiality, but is presumed to contain zirconium hexafluorozirconate, tri-valent chromium sulphate and fluoride constituents that are usually present in TCC baths. Consistent with the presence of such constituents, other work has shown that $\mathrm{ZrO}_{2}$, $\mathrm{Cr}(\mathrm{OH})_{s}, \mathrm{CrF}_{3}$ and $\mathrm{Cr}_{2}\left(\mathrm{SO}_{4}\right)_{3}$ are principal components of coatings formed in SurTec 650 chromitAL solution [9].

A three-electrode cell, containing a saturated calomel electrode ( $\mathrm{E}^{\mathrm{o}}=0.24 \mathrm{~V}$ vs NHE), a graphite cathode and a specimen with an exposed area of $\sim 2.25 \mathrm{~cm}^{2}$, was used for coating formation. Potentials were controlled by a Solarton electrochemical workstation with a Modulab software controller. First a potential of $+0.5 \mathrm{~V}_{\mathrm{SCE}}$ was applied for $10 \mathrm{~s}$ to activate the surface and then the potential was increased to -0.5 or $-1.5 \mathrm{~V}_{\mathrm{SCE}}$ for either 1200 or 2400 s. The time of the coating process was selected to be the same as (1200s) or greater than (2400s) the time used in previous work that revealed chromate species in a coating formed under the OCP condition $[9,13]$. The coated specimens were immediately removed from the cell and examined by Raman spectroscopy within $10 \mathrm{~s}$ to limit the possibility of oxidation of $\mathrm{Cr}^{3+}$ species in air. In addition, potentiodynamic polarization of electropolished aluminium was performed from -2 to $0 \mathrm{~V}_{\mathrm{SCE}}$ at $1 \mathrm{mV} / \mathrm{s}$ in the SurTec 650 chromitAL solution $\left(40^{\circ} \mathrm{C}, \mathrm{pH} 3.9\right)$. The specimen was first polarized at $+0.5 \mathrm{~V}_{\mathrm{SCE}}$ and then the potential was immediately switched to $-2.0 \mathrm{~V}_{\mathrm{SCE}}$ for the start of the potential scan. The experiments were repeated three times, revealing reproducible polarization behaviour.

\subsection{Characterization methods}

SEM-EDS employed a Zeiss Ultra 55 instrument at accelerating voltages of 3 and $15 \mathrm{kV}$. Raman spectroscopy used a Renishaw 2000 Raman instrument with an argon laser (wavelength $514 \mathrm{~nm}, 12.5 \mathrm{~mW}$ power). Calibration utilized a silicon peak at $520 \mathrm{~cm}^{-1}$ in the static mode. For specimen examination, the extended mode from 1200 to $200 \mathrm{~cm}^{-1}$ was employed with $30 \mathrm{~s}$ integration and 10-time accumulation to eliminate any background noise effect.

\section{Results and discussion}

Fig. 1 presents the polarization curve for electropolished aluminium in SurTec 650 solution $\left(40^{\circ} \mathrm{C}, \mathrm{pH}\right.$ 3.9) scanned from $-2.0 \mathrm{~V}_{\mathrm{SCE}}$ to 0 $\mathrm{V}_{\mathrm{SCE}}$. The current density in the cathodic branch rises to a peak value of

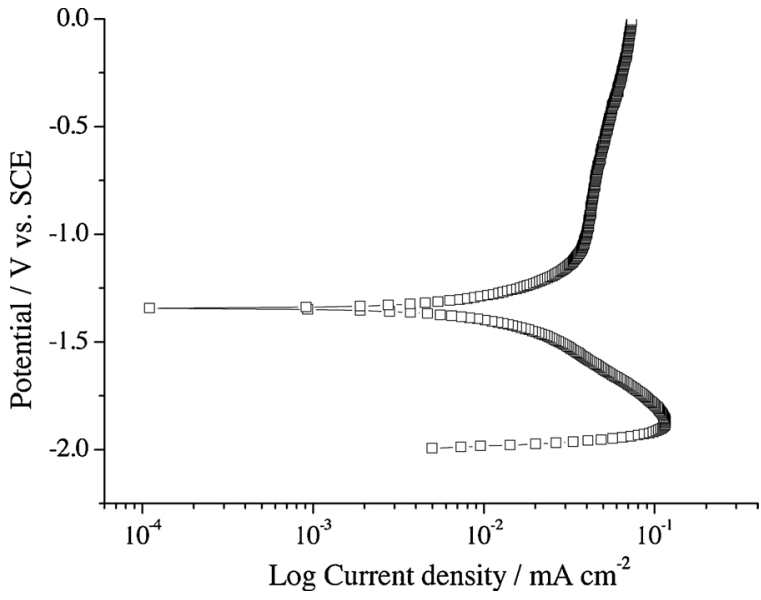

Fig. 1. Potentiodynamic polarization curve of electropolished aluminium during immersion in SurTec 650 chromitAL solution $\left(40^{\circ} \mathrm{C}, \mathrm{pH} 3.9\right)$ for $2000 \mathrm{~s}$.

$1.02 \times 10^{-4} \mathrm{~A} \mathrm{~cm}^{-2}$ at $-1.85 \mathrm{~V}_{\mathrm{SCE}}$ then decreases with a log-linear dependence on voltage over almost one decade of current density before decreasing steeply to zero net current density at $-1.34 \mathrm{~V}_{\mathrm{SCE}}$. The latter value compares with OCPs in the range -1.54 to $-1.50 \mathrm{~V}_{\mathrm{SCE}}$ reported previously for growth of a coating over a period of $1200 \mathrm{~s}$ in the same solution. The lower potential of zero current density in the polarization curve is due to the influence of the prior period of cathodic polarization. The decline in the magnitude of the cathodic current at potentials below $-1.85 \mathrm{~V}_{\mathrm{SCE}}$ can be attributed to the contribution of an anodic current density due to activation of the aluminium substrate. The net cathodic current density at higher potentials, which arises from reduction of $\mathrm{H}^{+}$ions, water molecules and dissolved oxygen, exceeds the anodic current density due to oxidation of aluminium. The current density in the anodic branch of the polarization curve rise steeply until a potential of about $-1.00 \mathrm{~V}_{\mathrm{SCE}}$, when the slope decreases sharply and the current density then rises slowly from $4 \times 10^{-5} \mathrm{~A} \mathrm{~cm}^{-2}$ to about $7 \times 10^{-5} \mathrm{~A} \mathrm{~cm}^{-2}$ at $0.0 \mathrm{~V}_{\mathrm{SCE}}$.

Coatings were prepared under constant potentials of -1.5 and $-0.5 \mathrm{~V}_{\mathrm{SCE}}$. At $-1.5 \mathrm{~V}_{\mathrm{SCE}}$, reduction of $\mathrm{H}^{+}$ions and dissolved oxygen can contribute to the cathodic current density. Oxygen reduction may be dominant at $-0.5 \mathrm{~V}_{\mathrm{SCE}}$ as the equilibrium potential for $\mathrm{H}^{+}$reduction is close to $-0.5 \mathrm{~V}_{\mathrm{SCE}}$ at the $\mathrm{pH}$ of the bulk solution (3.9). The former potential is close to the OCP potential for coatings formed by simple immersion in the naturally aerated solution. The current density during coating treatments for times of 1200s are shown in Fig. 2(a). The details of the first $200 \mathrm{~s}$ of treatment are shown in Fig. 2(b). For the treatment at $-1.5 \mathrm{~V}_{\mathrm{SCE}}$, the main features of the curve are an (i) increase in the net cathodic current density to $-0.75 \mathrm{~mA} \mathrm{~cm} \mathrm{~cm}^{-2}$ in the first $20 \mathrm{~s}$ of polarization followed by a fall to $-0.50 \mathrm{~mA} \mathrm{~cm} \mathrm{~cm}^{-2}$ after $30 \mathrm{~s}$; (ii) a plateau at $-0.45 \mathrm{~mA} \mathrm{~cm} \mathrm{~cm}^{-2}$ between $75-200 \mathrm{~s}$; (iii) a decrease at a progressively reducing to a final current density of $-0.26 \mathrm{~mA} \mathrm{~cm}^{-2}$. Thus, the specimen was cathodically polarized over the whole of the treatment time. The polarization at $-0.5 \mathrm{~V}_{\mathrm{SCE}}$ resulted in a net anodic current density throughout the coating process, comprising an initial rapid rise in current density to $1.8 \mathrm{~mA} \mathrm{~cm}^{-2}$ during the initial $20 \mathrm{~s}$ followed by a smooth decrease at a reducing rate to reach a final value of $0.4 \mathrm{~mA} \mathrm{~cm}^{-2}$. Notably, the current density in the potentiodynamic polarization curve at $-0.5 \mathrm{~V}_{\mathrm{SCE}}$, namely $0.03 \mathrm{~mA} \mathrm{~cm}^{-2}$, is lower than the final value of the potentiostatic curve $\left(0.4 \mathrm{~mA} \mathrm{~cm}^{-2}\right)$. It is due to the much greater coating thickness that results from the prior cathodic polarization of the specimen at the start of the polarization scan. The strong influence of cathodic polarization on the coating thickness is evident in the results from EDS analyses presented later. In addition, the curves for both -1.5 and $-0.5 \mathrm{~V}_{\mathrm{SCE}}$ shows rapid increases in the current density in the first $20 \mathrm{~s}$ of polarization. This is probably due to thinning of the oxide film that was present on the surface of the 




(b)

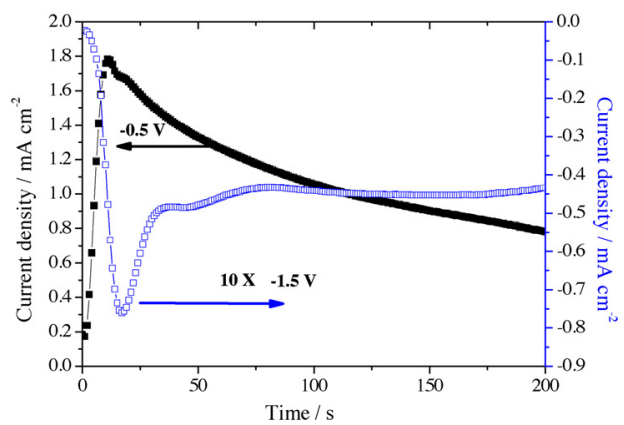

Fig. 2. (a) Current transients obtained during potentiostatic polarization of aluminium in SurTec 650 chromitAL solution $\left(40^{\circ} \mathrm{C}, \mathrm{pH} \mathrm{3.9)}\right.$ at -0.5 and $-1.5 \mathrm{~V}_{\mathrm{SCE}}$ for $1200 \mathrm{~s}$. (b) Detail of the initial $200 \mathrm{~s}$.

electropolished aluminium specimens. Thereafter, growth of the coating causes the net anodic and cathodic current densities to decrease.

Fig. 3(a-d) presents scanning electron micrographs of TCC coatings formed at the OCP $\left(\approx-1.45 \mathrm{~V}_{\mathrm{SCE}}\right)$ for $1200 \mathrm{~s},-0.5 \mathrm{~V}_{\mathrm{SCE}}$ for 1200 and $2400 \mathrm{~s}$ and at $-1.5 \mathrm{~V}_{\mathrm{SCE}}$ for $1200 \mathrm{~s}$. A smooth coating surface resulted in most regions of all coatings. However, the coatings contained cracks generated by dehydration and shrinkage of the coating material during drying. The coatings also contained deposits of solution precipitates [14], which are evident as granular features of white appearance at the coating surface. The cracks in the coatings formed at the OCP and $-1.5 \mathrm{~V}_{\mathrm{SCE}}$ for 1200 s formed a continuous network. In contrast, cracks in the coating formed at $-0.5 \mathrm{~V}_{\mathrm{SCE}}$, often propagated short distances from the points of initiation and did not connect with other cracks. This difference in the crack morphology is possibly related to differing degrees of hydration of the coating material, and hence in the magnitude of the stresses caused by shrinkage of the coating, and also to differing coating thicknesses. The cracking, which has been reported previously in similar coatings $[9,17]$, is likely to have been exacerbated by exposure to vacuum of the microscope.

Fig. 4 shows results of EDS spot analyses made at an accelerating voltage of $15 \mathrm{kV}$ on the surface of coatings formed at the OCP $\left(-1.45 \mathrm{~V}_{\mathrm{SCE}}\right),-0.5$ and $-1.5 \mathrm{~V}_{\mathrm{SCE}}$ for $1200 \mathrm{~s}$. The analyses were made remote from locations of cracks. A coating was also formed for 2400 s at $-0.5 \mathrm{~V}_{\mathrm{SCE}}$. After coating formation, the specimens were immersed in deionized water for $120 \mathrm{~s}$ and dried in a cool-air stream. The spectra contain peaks from oxygen, aluminium, fluorine, zirconium and chromium in the coating and of carbon from adsorbed contaminant. According to previous X-ray photoelectron spectroscopy, $\mathrm{ZrO}_{2}, \mathrm{Cr}(\mathrm{OH})_{\mathrm{s}}$, $\mathrm{CrF}_{3}$ and $\mathrm{Cr}_{2}\left(\mathrm{SO}_{4}\right)_{3}$ are the main constituents of the outer layer of the coating [9]. Insufficient sulphur was present in the coating for the sulphur $\mathrm{K} \alpha$ peak at $2.307 \mathrm{keV}$ to be clearly resolved in the spectra Fig. 4. The additional, much higher peak in the spectra originating from aluminium mainly results from X-ray generation from the aluminium substrate that dominates the contribution from aluminium in the inner alumina-rich layer of the coating, which also contains a significant amount of fluorine $[9,18]$. The SurTec solution contains hydrolysed trivalent chromium and zirconium species $[13,19]$, which form deposits of the coating material on the aluminium surface as a result of the increases in $\mathrm{pH}$ that results from the reduction of $\mathrm{H}^{+}$ions and dissolved oxygen $[8,16]$. The highest peaks for fluorine, zirconium and chromium were associated with the cathodically polarized specimen coated at $-1.5 \mathrm{~V}_{\mathrm{SCE}}$ for $1200 \mathrm{~s}$. The lowest peaks occurred for the anodically polarized specimen coated at $-0.5 \mathrm{~V}_{\mathrm{SCE}}$ for $1200 \mathrm{~s}$. The peaks for the coating formed at the OCP for 1200s were between those of the previous coatings. Taking the height of the zirconium peak as an indicator of the coating thickness, the cathodically polarized aluminium was about 2.5 times thicker than that on specimens coated at the OCP and about 6 times thicker than the coating formed at $-0.5 \mathrm{~V}_{\text {SCE }}$. The EDS results indicate the significant increase in the rate of coating growth that can be achieved by reducing potential below the OCP. In contrast, the rate of growth is significantly lowered at potentials above the OCP. In the present instance, the rate of growth of the coating formed at $-0.5 \mathrm{~V}_{\mathrm{SCE}}$ was about 2.5 times slower than at the OCP. The coating thickness of the anodically polarized specimen was increased by about a factor of two by doubling the treatment time from 1200 s to 2400s [15].

Fig. 5 shows Raman spectra of the coated specimens treated for $1200 \mathrm{~s}$ at the OCP, $-1.5 \mathrm{~V}$ and $-0.5 \mathrm{~V}$ vs SCE. In all spectra, zirconium oxide was identified by peaks at 470 and $537 \mathrm{~cm}^{-1}$ and chromium sulphate at $998 \mathrm{~cm}^{-1}$. The peak around $810 \mathrm{~cm}^{-1}$ is associated with aluminium hydroxides [6]. The spectra for coatings formed at $-1.5 \mathrm{~V}_{\mathrm{SCE}}$ and the OCP had an additional peak for $\mathrm{Cr}^{6+}$ species at $866 \mathrm{~cm}^{-1}$. This peak was not resolved at $-0.5 \mathrm{~V}$ even when the treatment was extended to 2400s. After this time of treatment, the EDS analyses showed that the coating thickness was similar to that of the coating formed at the OCP. This difference in the spectra indicates the much greater presence of $\mathrm{Cr}^{6+}$ species in the coatings formed at the more negative potentials. The chromate species result from the oxidation of $\mathrm{Cr}^{3+}$ species by the $\mathrm{H}_{2} \mathrm{O}_{2}$ generated by oxygen reduction, which can occur by two pathways:

$\mathrm{O}_{2}+2 \mathrm{H}^{+}+2 \mathrm{e}^{-} \rightarrow \mathrm{H}_{2} \mathrm{O}_{2}\left(\mathrm{E}^{\mathrm{o}}=+0.44 \mathrm{~V}\right.$ vs. SCE $)$

$\mathrm{O}_{2}+4 \mathrm{H}^{+}+4 \mathrm{e}^{-} \rightarrow 2 \mathrm{H}_{2} \mathrm{O}\left(\mathrm{E}^{\mathrm{o}}=+0.99 \mathrm{~V}\right.$ vs. SCE)

The relative contributions of Reactions (1) and (2) to the overall oxygen reduction current on the present specimens is unknown, but is likely to depend upon the coating composition, the presence of adsorbed species, the solution $\mathrm{pH}$ adjacent to the specimen surface and the electrode potential [17]. For instance, the oxygen reduction current due to Reaction (1) has been shown to depend upon the substrate composition and to increase at more cathodic potentials [17]. Cathodic polarization of aluminium can also encourage the formation of hydrogen peroxide from reaction of hydroperoxyl radicals, as follows [20],

$\left(\mathrm{O}_{2}\right)_{\mathrm{ads}}+\mathrm{H}^{+}+\mathrm{e} \rightarrow \mathrm{HO}_{2} \cdot(\mathrm{pH}<4.8)$

$\mathrm{HO}_{2} \cdot+\mathrm{HO}_{2}^{\cdot} \rightarrow \mathrm{H}_{2} \mathrm{O}_{2}+\mathrm{O}_{2}$

$\mathrm{Cr}^{3+}$ oxidation in TCC coatings can be mitigated using an addition to the bath that can be preferentially oxidized by $\mathrm{H}_{2} \mathrm{O}_{2}$. Xia et al. [21] reported the effectiveness of $\mathrm{IrCl}_{6}{ }^{-3 /-2}, \mathrm{Fe}^{+3 /+2}, \mathrm{~V}^{+3 /+2}$ and $\mathrm{Fe}(\mathrm{CN})_{6}^{-}$ ${ }^{3 /-4}$. For instance, the standard potentials of $\mathrm{IrCl}_{6}{ }^{-3 /-2}$ and $\mathrm{Cr}^{6+} / \mathrm{Cr}^{3+}$ are +1.02 and $+1.33 \mathrm{~V}_{\mathrm{NHE}}$ respectively, and the Gibbs free energy of the $\mathrm{IrCl}_{6}{ }^{-3 /-2}$ redox system is lower than that of chromium system. Thus, $\mathrm{IrCl}_{6}{ }^{-3 /-2}$ can be preferentially oxidized by $\mathrm{H}_{2} \mathrm{O}_{2}$. Our previous work employed $\mathrm{Fe}^{+3 /+2}$ additions to the SurTec solutions to restrict $\mathrm{Cr}^{6+}$ formation in freshly-formed TCC coatings on AA2024 alloy [22].

\section{Conclusions}

1 The present work, focused on the influence of applied potential on 

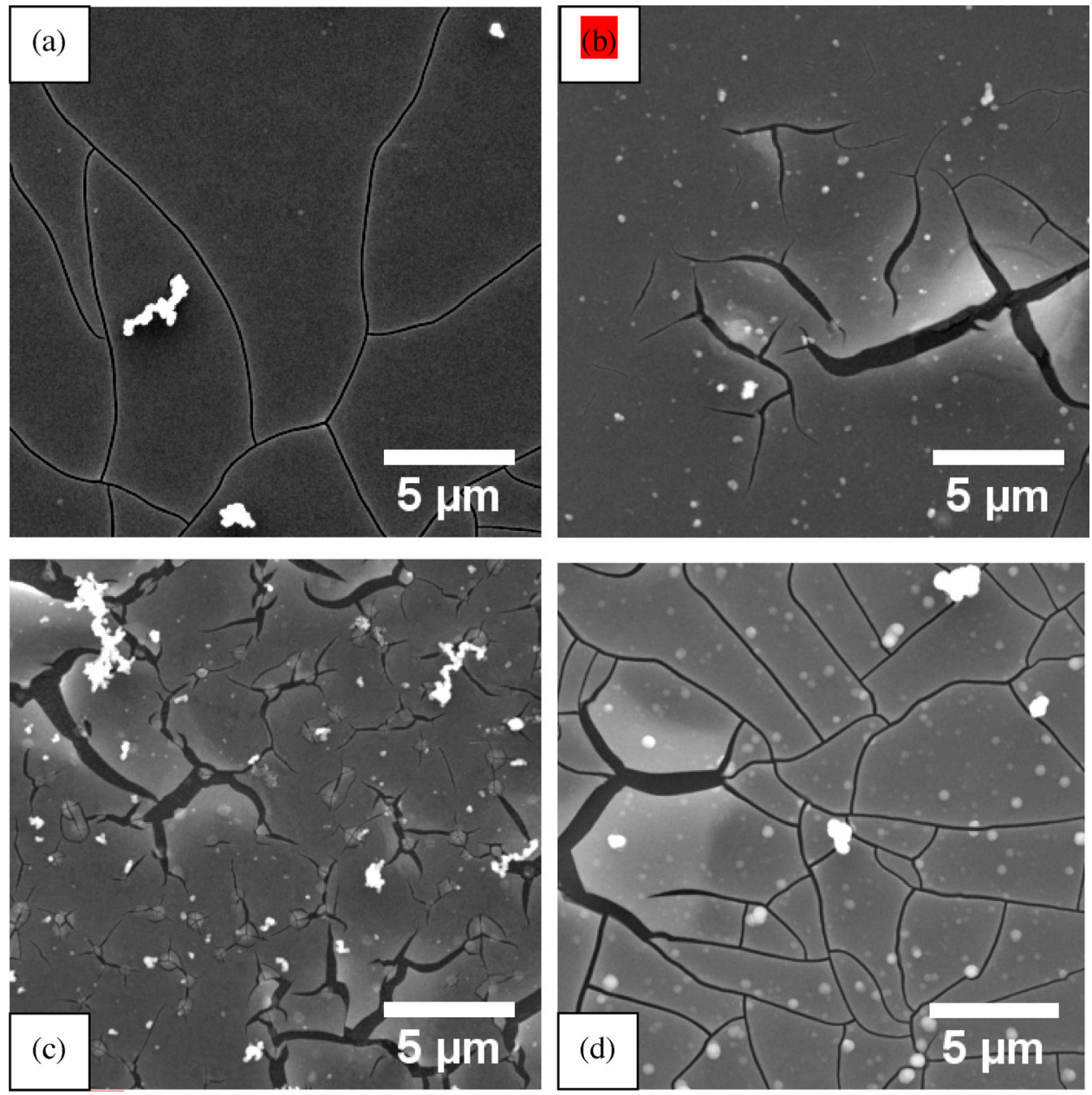

Fig. 3. Scanning electron micrographs of TCC coatings formed at the (a) OCP for $1200 \mathrm{~s}$, (b) $-0.5 \mathrm{~V}_{\mathrm{SCE}}$ for $1200 \mathrm{~s}$, (c) $-0.5 \mathrm{~V}_{\mathrm{SCE}}$ for $2400 \mathrm{~s}$ and (c) $-1.5 \mathrm{~V}_{\mathrm{SCE}}$ for 1200 s.

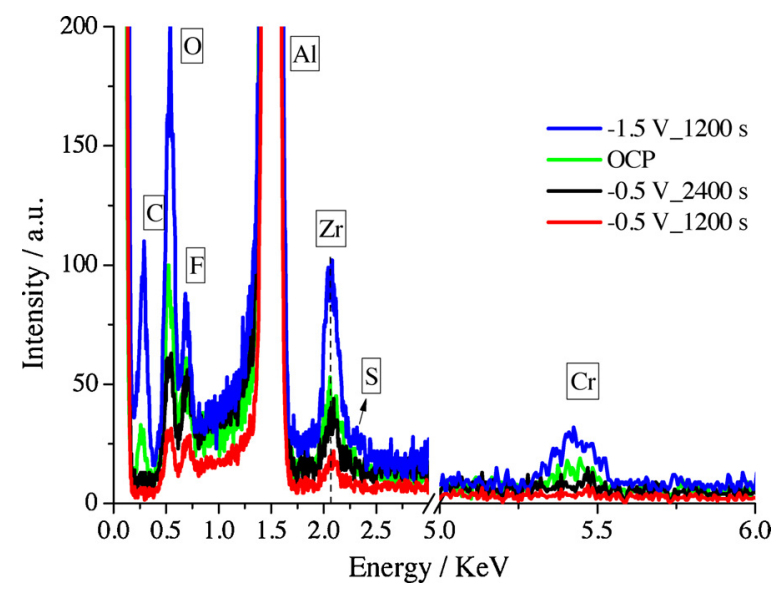

Fig. 4. SEM/EDS spectra for fluoride, zirconium and chromium components in coatings formed on aluminium in SurTec 650 chromitAL solution $\left(40^{\circ} \mathrm{C}, \mathrm{pH}\right.$ $3.9)$ at the OCP and -0.5 and $-1.5 \mathrm{~V}_{\mathrm{SCE}}$ for $1200 \mathrm{~s}$ and $-0.5 \mathrm{~V}_{\mathrm{SCE}}$ for $2400 \mathrm{~s}$.

the chromium valence state in freshly-formed coatings on aluminium, provides new insights into the effect of the potential on the coating morphology and the formation of $\mathrm{Cr}^{6+}$ species. Cathodic polarization at $-1.5 \mathrm{~V}_{\mathrm{SCE}}$ led to a coating about 2.5 times thicker than one formed at the OCP and about 6 times thicker than the one formed under anodic polarization $\left(-0.5 \mathrm{~V}_{\mathrm{SCE}}\right)$. The thickening of the coating is due to enhanced by increasing polarization of the

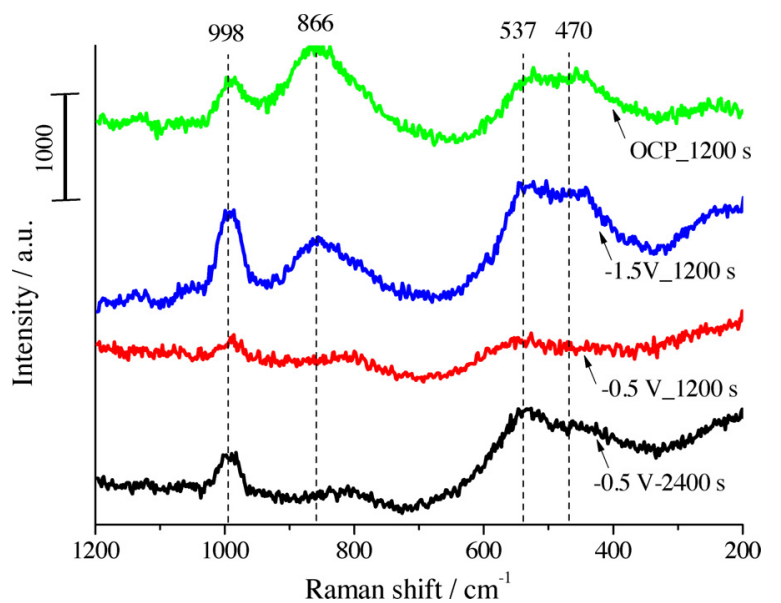

Fig. 5. Raman spectra of coatings formed on aluminium in SurTec 650 chromitAL solution $\left(40{ }^{\circ} \mathrm{C}, \mathrm{pH} 3.9\right)$ at the OCP and -0.5 and $-1.5 \mathrm{~V}_{\mathrm{SCE}}$ for $1200 \mathrm{~s}$ and $-0.5 \mathrm{~V}_{\mathrm{SCE}}$ for $2400 \mathrm{~s}$.

cathodic reaction that increases the local $\mathrm{pH}$ at the coating surface. 2 Raman spectroscopy revealed $\mathrm{Cr}^{6+}$ species in a coating freshlyformed under cathodic polarization at of $-1.5 \mathrm{~V}_{\mathrm{SCE}}$. However, such species were not detectable in a coating formed at $-0.5 \mathrm{~V}_{\mathrm{SCE}}$. The latter is attributed to reduced generation of $\mathrm{H}_{2} \mathrm{O}_{2}$ by the oxygen reduction reaction and hence reduced availability of $\mathrm{H}_{2} \mathrm{O}_{2}$ to oxidize 
$\mathrm{Cr}^{3+}$ species.

\section{Author statement}

Jiantao Qi carried out the data curation and writing-Original draft preparation; Jolanta Światowska provided the Raman methodology and validation; Peter Skeldon carried out the investigation, reviewing and editing; Philippe Marcus carried out the paper writing - reviewing and editing. All authors contributed to the interpretation of the results and to the writing of the paper.

\section{Declaration of Competing Interest}

The authors declare that they have no known competing financial interests or personal relationships that could have appeared to influence the work reported in this paper.

\section{Acknowledgements}

The authors thank the National Natural Science Fund (51701239), Shandong Natural Science Fund (ZR2017LEM005) Fundamental Research Funds for the Central Universities (18CX02128A) and the LATEST2 Programme Grant (EP/H020047/1) for the financial support of this work.

\section{References}

[1] M.W. Kendig, R.G. Buchheit, Corrosion inhibition of aluminum and aluminum alloys by soluble chromates, chromate coatings, and chromate-free coatings, Corrosion 59 (2003) 379-400, https://doi.org/10.5006/1.3277570.

[2] D.B. Mitton, A. Carangelo, A. Acquesta, T. Monetta, M. Curioni, F. Bellucci, Selected $\mathrm{Cr}(\mathrm{VI})$ replacement options for aluminum alloys: a literature survey, Corros. Rev. 35 (2017) 365-381, https://doi.org/10.1515/corrrev-2016-0059.

[3] M. Ely, J. Światowska, A. Seyeux, S. Zanna, P. Marcus, Role of post-treatment in improved corrosion behavior of trivalent chromium protection (TCP) coating deposited on aluminum alloy 2024-T3, J. Electrochem. Soc. 164 (2017) C276-C284, https://doi.org/10.1149/2.0431706jes.

[4] X. Verdalet-Guardiola, B. Fori, J.-P. Bonino, S. Duluard, C. Blanc, Nucleation and growth mechanisms of trivalent chromium conversion coatings on 2024-T3 aluminium alloy, Corros. Sci. 155 (2019) 109-120, https://doi.org/10.1016/j.corsci. 2019.04.035.

[5] Y. Guo, G.S. Frankel, Characterization of trivalent chromium process coating on AA2024-T3, Surf. Coat. Technol. 206 (2012) 3895-3902, https://doi.org/10.1016/ j.surfcoat.2012.03.046.

[6] C.A. Munson, S.A. McFall-Boegeman, G.M. Swain, Cross comparison of TCP conversion coating performance on aluminum alloys during neutral salt-spray and thinlayer mist accelerated degradation testing, Electrochim. Acta 282 (2018) 171-184, https://doi.org/10.1016/j.electacta.2018.04.115.

[7] L.L. Li, G.P. Swain, A. Howell, D. Woodbury, G.M. Swain, The formation, structure, electrochemical properties and stability of trivalent chrome process (TCP) coatings on AA2024, J. Electrochem. Soc. 158 (2011) C274-C283, https://doi.org/10.1149/ 1.3607980 .

[8] X.C. Dong, P. Wang, S. Argekar, D.W. Schaefer, Structure and composition of trivalent chromium process (TCP) films on Al alloy, Langmuir 26 (2010) 10833-10841, https://doi.org/10.1021/la100699u.

[9] J.T. Qi, T. Hashimoto, J.R. Walton, X. Zhou, P. Skeldon, G.E. Thompson, Trivalent chromium conversion coating formation on aluminium, Surf. Coat. Technol. 280 (2015) 317-329, https://doi.org/10.1016/j.surfcoat.2015.09.024.

[10] C.A. Munson, G.M. Swain, Structure and chemical composition of different variants of a commercial trivalent chromium process (TCP) coating on aluminum alloy 7075-T6, Surf. Coat. Technol. 315 (2017) 150-162, https://doi.org/10.1016/j surfcoat.2017.02.018.

[11] R. Viroulaud, J. Światowska, A. Seyeux, S. Zanna, J. Tardelli, P. Marcus, Influence of surface pretreatments on the quality of trivalent chromium process coatings on aluminum alloy, Appl. Surf. Sci. 423 (2017) 927-938, https://doi.org/10.1016/j. apsusc. 2017.06.246.

[12] J. Qi, J. Walton, G.E. Thompson, S.P. Albu, J. Carr, Spectroscopic studies of chromium VI formed in the trivalent chromium conversion coatings on aluminum, J. Electrochem. Soc. 163 (2016) C357-C363, https://doi.org/10.1149/2.0531607jes.

[13] J. Qi, L. Gao, Y. Liu, B. Liu, T. Hashimoto, Z. Wang, G.E. Thompson, Chromate formed in a trivalent chromium conversion coating on aluminum, J. Electrochem. Soc. 164 (2017) C442-C449, https://doi.org/10.1149/2.0021709jes.

[14] L.L. Li, D.Y. Kim, G.M. Swain, Transient formation of chromate in trivalent chromium process (TCP) coatings on AA2024 as probed by Raman spectroscopy, J. Electrochem. Soc. 159 (2012) C326-C333, https://doi.org/10.1149/2.019208jes.

[15] J. Qi, T. Hashimoto, J. Walton, X. Zhou, P. Skeldon, G.E. Thompson, Formation of a trivalent chromium conversion coating on AA2024-T351 alloy, J. Electrochem. Soc 163 (2016) C25-C35, https://doi.org/10.1149/2.0771602jes.

[16] X.C. Dong, S. Argekar, P. Wang, D.W. Schaefer, In situ evolution of trivalent chromium process passive film on $\mathrm{Al}$ in a corrosive aqueous environment, ACS Appl. Mater. Interfaces 3 (2011) 4206-4214, https://doi.org/10.1021/am200845v.

[17] J. Qi, G. Thompson, Comparative studies of thin film growth on aluminium by AFM, TEM and GDOES characterization, Appl. Surf. Sci. 377 (2016) 109-120, https://doi. org/10.1016/j.apsusc.2016.03.115.

[18] J. Qi, T. Hashimoto, G.E. Thompson, J. Carr, Influence of water immersion posttreatment parameters on trivalent chromium conversion coatings formed on AA2024-T351 alloy, J. Electrochem. Soc. 163 (2016) C131-C138, https://doi.org/ $10.1149 / 2.0221605$ jes.

[19] D. Chidambaram, C.R. Clayton, G.P. Halada, The role of hexafluorozirconate in the formation of chromate conversion coatings on aluminum alloys, Electrochim. Acta 51 (2006) 2862-2871, https://doi.org/10.1016/j.electacta.2005.08.022.

[20] S.H. Joo, A.J. Feitz, T.D. Waite, Oxidative degradation of the carbothioate herbicide, molinate, using nanoscale zero-valent iron, Environ. Sci. Technol. 38 (2004) 2242-2247, https://doi.org/10.1021/es035157g.

[21] L. Xia, R.L. McCreery, Structure and function of ferricyanide in the formation of chromate conversion coatings on aluminum aircraft alloy, J. Electrochem. Soc. 146 (1999) 3696-3701, https://doi.org/10.1149/1.1392536.

[22] J. Qi, B. Zhang, Z. Wang, Y. Li, P. Skeldon, G.E. Thompson, Effect of an Fe(II)modified trivalent chromium conversion process on $\mathrm{Cr}(\mathrm{VI})$ formation during coating of AA 2024 alloy, Electrochem. Commun. 92 (2018) 1-4, https://doi.org/ 10.1016/j.elecom.2018.05.013. 